\title{
Predacious Activity of Ants (Hymenoptera: Formicidae) in Conventional and in No-till Agriculture Systems
}

\author{
Denise Lange ${ }^{1}$, Wedson Desidério Fernandes ${ }^{1,2^{*}}$, Josué Raizer ${ }^{1,2}$ and Odival Faccenda ${ }^{3}$ \\ ${ }^{1}$ Universidade Federal da Grande Dourados, Dourados - MS - Brasil. ${ }^{2}$ Faculdade de Ciências Biológicas e \\ Ambientais; Rodovia Dourados-Itahum, km 12; wedson@ufgd.edu.br; 79804-970; Dourados - MS - Brasil. \\ ${ }^{3}$ Universidade Estadual de Mato Grosso do Sul; Rodovia Dourados-Itahum, km 12; 79804-970; Dourados - MS - \\ Brasil
}

\begin{abstract}
This study had the objective of assessing the differences in foraging activity of the predacious ants between two areas, one conventional and other with no-till agriculture systems. The research was conducted in two contiguous 1.5 ha plots in Dourados MS, Brazil, from February 2001 to December 2003. Each plot received 750 baits (Nasutitermes termites), 425 at daylight and 325 at night. The termites were placed on the filter paper, on the ground, and ant attack was monitored for $15 \mathrm{~min}$, until removed. Sixteen ant species were found in the no-till system and nine in the conventional system. Baits removed from no-till were significantly higher than the conventional plots and were influenced by the sampling time, at day or night. The seasons of the year did not significantly explain the variations in the structure of the predacious ant communities in neither of the systems. The significant differences at foraging activity and ant richness between the areas indicated that the no-tillage system could improve environmental quality of the cropping and therefore, became an important tool for the integrated pest management programs.
\end{abstract}

Key words: Agroecosystems, biological control, community structure, soil tillage, species richness, predation effects

\section{INTRODUCTION}

The ants are among the main biotic components of most environments because of their high species richness, their diversity to be positively related to the environmental complexity (Estrada and Fernández, 1999) and importance for the material and energy flux in ecosystems (Alonso and Agosti, 2000). A large number of studies on the ant communities in the tropics were conducted in the natural ecosystems, although the evidence of similar ant functions in the agroecosystems can be found, particularly among the communities of the insects considered pests (Samways, 1983; Mansfield et al., 2003; Rossi and Fowler, 2004) or weeds (Risch and Carroll, 1982).

The studies conducted in the Dourados region (MS, Brazil) showed the genera of Pheidole, Solenopsis, Dorymyrmex and Ectatomma as the insect predators in soybean (Fernandes et al., 1999). Solenopsis and Pheidole were the most constant and were also seen attacking Anticarsia gemmatalis Hübner (Lepidoptera: Noctuidae) larvae in the soil (Fernandes et al., 1999; 2000).

\footnotetext{
Author for correspondence
} 
Sterling (1978) found that the ant Solenopsis invicta Buren efficiently controlled the boll weevil (Anthonomus grandis Boheman, Curculionidae) reaching $85 \%$ of control efficacy.

No-tillage agroecosystems increase the structural complexity of the environment, leading to improved conditions for the development of a richer epigeic fauna. According to Gassen (1989), the soils covered with straw give rise to more complex community relations than the soils with the crops under conventional tillage. Greater complexity may induce to more abundant and more diversified natural enemy populations of crop pests, thus decreasing the density of the phytophagous insects (Garcia and Altieri, 1992). High populations of predators and parasitoids underneath the straw improve the pest natural biological control. According to the natural enemy hypothesis (Root, 1973; Altieri et al., 2003), the more complex the environment, the greater the diversity of microhabitats and preys. This conducts to relatively constant generalist predator populations that can exploit the herbivores, becoming available at different times and in different microhabitats.

In this study, the differences in predacious ant foraging activity between two agricultural plots, was assessed, one in no-tillage and other in the conventional system. The variations in predacious ant assemblage structure between plots along the time were also evaluated.

\section{MATERIALS AND METHODS}

\section{Research site}

The data were collected at the por campus da Universidade Federal da Grande Dourados (UFGD) in Dourados, MS (22 $13^{\prime} 16^{\prime \prime} S$ and $\left.54^{\circ} 48^{\prime} 20^{\prime \prime} \mathrm{W}\right)$, from February 2001 to December 2003. The samples were collected from two contiguous cropping plots, with 1.5 ha each. Since 1999 , one of the plots was under the conventional and the other under no-till system. The summer crops were soybean and corn, and the winter crops were wheat, vetch, forage turnip, and black oat. The cultivars, planting dates, and crop management systems were the same for both the sites, during the data collection period.

\section{Data collection and analysis}

The ant species frequency and bait (worker termites of the genus Nasutitermes) removal time in both the areas were recorded following the methodology used by Saks and Carroll (1980). One termite was placed on a circular filter paper (10 cm diameter) on the ground. The termite was observed 15 minutes or upon removal by an ant. The ants observed removing baits were collected and identified, following Bolton (1994). Voucher specimens of the ants are deposited at the reference collection of the Laboratório de Ecologia de Insetos, Faculdade de Ciências Biológicas e Aplicadas, Universidade Federal da Grande Dourados/UFGD, at Dourados, MS, Brazil. The experiment was initiated only at the daytime with 50 baits randomly distributed on each plot. Baits were kept at least 10 apart. After December/2001 observations at night were also made (50 baits at daytime between 2 and 5 p.m. and at night between 6 and 9 p.m., except in December/2001, with 25 baits in each plot, see Table 1 for details about replications). At night, a red-filter flashlight was used to minimize light direct impact on the ant behavior. Differences in the proportion of the ant-removed baits at the daylight and at night, between tillage systems, were statistically analyzed by the Chi-square test, following the contingency tables.

The ant assemblage was studied by recording the species richness by rarefaction for each year in each plot. The occurrence frequency per observation was used for the estimates. To obtain the mean species and confidence intervals at $95 \%$, a design of randomized independent samples with 1000 iterations by using the software EcosSim 7.0 (Gotelli and Entsminger, 2001) was used. 
Table 1 - Number of termite baits removed by ants in two tillage systems, at day and night times, from February 2001 to December 2003. The total number of baits observed for up to 15 minutes is in parenthesis.

\begin{tabular}{lcccc}
\hline & \multicolumn{3}{c}{ Tillage system } \\
\cline { 2 - 5 } Observation periods & \multicolumn{2}{c}{ Conventional tillage } & No-till \\
\cline { 2 - 5 } & \multicolumn{1}{c}{ Day } & Night & $22(50)$ & Night \\
\hline Feb/2001 & $10(50)$ & $0(0)$ & $13(50)$ & $0(0)$ \\
Aug/2001 & $10(50)$ & $0(0)$ & $15(25)$ & $11(25)$ \\
Dec/2001 & $8(25)$ & $9(25)$ & $3(50)$ & $0(50)$ \\
Jun/2002 & $2(50)$ & $2(50)$ & $24(50)$ & $19(50)$ \\
Oct-Dec/2002 & $11(50)$ & $3(50)$ & $11(50)$ & $4(50)$ \\
Jan-Mar/2003 & $18(50)$ & $5(50)$ & $1(50)$ & $0(50)$ \\
Apr-Jun/2003 & $5(50)$ & $1(50)$ & $5(50)$ & $10(50)$ \\
Jul-Sep/2003 & $0(50)$ & $1(50)$ & $9(50)$ & $3(50)$ \\
Oct-Dec/2003 & $9(50)$ & $20(50)$ & & \\
\hline
\end{tabular}

To obtain one representative gradient of the ant assemblage structure, the frequency data on the species occurrence were used to order the nine observation periods for the two areas $(n=18$ observations), by principal coordinates analysis (PCoA). The Bray-Curtis (Bray and Curtis, 1957) index was used to calculate the dissimilarity between the observation periods in both the tillage systems. The values for the occurrence frequency were transformed into relative frequency per observation period and plot, to isolate the sample size effect from these indexes. Pillai-Trace statistics for a multivariate covariance analysis was used to find out if the ant assemblage structure obtained by the PCoA could be explained by the tillage system or by the season of the year.

\section{RESULTS}

The ants belonged to four subfamilies, nine genera, and 16 morphospecies (Table 2). Most of the ants removing termite baits belonged to the genus Pheidole and showed high foraging efficiency, as well as Dorymyrmex and Solenopsis in both sites. Camponotus sp.1, Crematogaster sp.1, Ectatomma planidens, and Odontomachus haematodus took longer to remove the baits, as compared with the ants from the genera Myrmicinae and Dolichoderinae (Table 2). The proportion of baits removed in the no-till (167 from 750) and in the conventional tillage areas (97 from 750) depended on the sampling time, day or night (Mantel-Haenszel $\chi^{2}=22.166 ; p<0.001$ ). At either times, the proportion of the baits removed by the ants was significantly higher in the notillage areas $\left(\chi^{2}\right.$ with Yates correction $=9.025, \mathrm{gl}$ $=1 ; \mathrm{p}=0.003)$. The species Hylomyrma sp.1, Odontomachus haematodus, Camponotus sp.1, and Camponotus sp.2 were only found during the day (Table 2).

Considering all times (day and night) and observation periods from February 2001 to December 2003, and the total of 750 baits in each plot, the highest ant efficiency in removing the termite baits occurred in the no-till area (Fig. 1).

The ant assemblage was studied by recording the species richness by rarefaction for each year in each plot. The occurrence frequency per observation was used for the estimates. 
Table 2 - Number of ant species observed removing termite baits, in two tillage systems and at two times (day and night), in the Dourados region, MS State, Brazil. Average time (min) for ants to find and remove baits is in parenthesis.

\begin{tabular}{|c|c|c|c|c|c|}
\hline \multirow{3}{*}{ TAXA } & \multicolumn{4}{|c|}{ Tillage System } & \multirow{3}{*}{$\begin{array}{c}\text { Total } \\
n=1500\end{array}$} \\
\hline & \multicolumn{2}{|c|}{ Conventional } & \multicolumn{2}{|c|}{ No-till } & \\
\hline & $\begin{array}{c}\text { Day } \\
n=425\end{array}$ & $\begin{array}{l}\text { Night } \\
n=325\end{array}$ & $\begin{array}{c}\text { Day } \\
n=425\end{array}$ & $\begin{array}{l}\text { Night } \\
n=325\end{array}$ & \\
\hline \multicolumn{6}{|l|}{ Myrmicinae } \\
\hline Pheidole sp.1 & $23(4.7)$ & $10(5.4)$ & $30(5.4)$ & $24(7.2)$ & $87(5.7)$ \\
\hline Pheidole sp.2 & $12(7.4)$ & $5(7.8)$ & $12(7.9)$ & $17(5.8)$ & $46(7.0)$ \\
\hline Pheidole sp.3 & $2(3.0)$ & - & $1(11.0)$ & $1(9.0)$ & $4(6.2)$ \\
\hline Pheidole sp.4 & $1(4.0)$ & - & $4(4.2)$ & $1(1.0)$ & $6(3.7)$ \\
\hline Pheidole sp.5 & $1(10.0)$ & - & $2(3.5)$ & $5(7.6)$ & $8(6.9)$ \\
\hline Pheidole sp. 6 & - & - & & $1(1.0)$ & $1(1.0)$ \\
\hline Solenopsis sp.1 & $7(6.6)$ & $5(8.2)$ & $8(7.1)$ & $9(6.4)$ & $29(7.0)$ \\
\hline Solenopsis sp.2 & - & - & $3(5.6)$ & $1(2.0)$ & $4(4.7)$ \\
\hline Hylomyrma sp.1 & - & - & $3(7.7)$ & & $3(7.7)$ \\
\hline Crematogaster sp. 1 & - & $1(15.0)$ & $2(9.5)$ & $1(8.0)$ & $4(10.5)$ \\
\hline \multicolumn{6}{|l|}{ Dolichoderinae } \\
\hline Dorymyrmex sp.1 & $24(6.2)$ & $3(3.3)$ & $26(5.5)$ & $1(1.0)$ & $54(5.6)$ \\
\hline Linepithema sp.1 & - & - & $1(10.0)$ & $1(6.0)$ & $2(8.0)$ \\
\hline Ponerinae & - & - & - & - & - \\
\hline Ectatomma planidens Borgmeier & $3(5.3)$ & - & $4(12.2)$ & $2(13.5)$ & $9(10.2)$ \\
\hline Odontomachus haematodus Linnaeus & - & - & $3(7.7)$ & - & $3(7.7)$ \\
\hline Formicinae & - & - & & - & - \\
\hline Camponotus sp. 1 & - & - & $1(2)$ & - & $1(2.0)$ \\
\hline Camponotus sp.2 & - & - & $3(9.7)$ & - & $3(9.7)$ \\
\hline Total & $73(5.8)$ & $24(6.6)$ & $103(6.4)$ & $64(6.6)$ & $264(6.3)$ \\
\hline
\end{tabular}

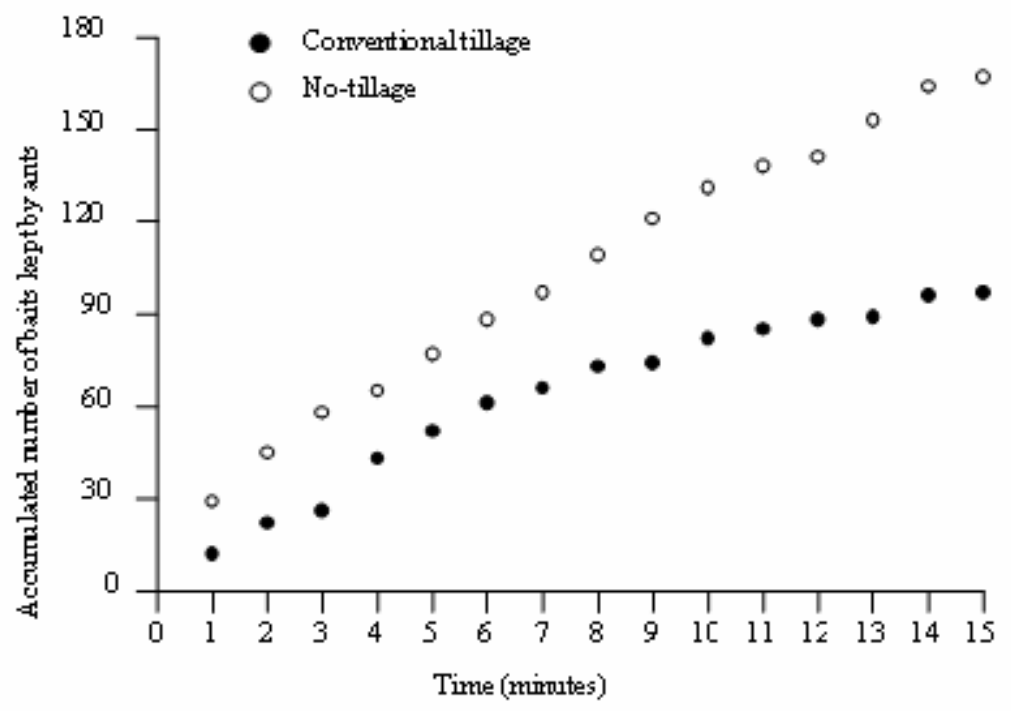

Figure 1 - Accumulated number of baits kept by ants in conventional tillage and in no-tillage area for 15-minute observations. In each site, 750 baits were randomly distributed in day and night periods, between February 2001 and December 2003. 
The estimations of the species richness for each observation year showed that after the second observation year (considering the $95 \%$ confidence interval of the estimation), the expected number of the species for the no-till and for the conventional systems changed in opposite directions, increased for the no-till (Fig. 2).

The ordination (PCoA) of the ant species samples captured $65.8 \%$ of the variation in the original distances in two axis (Fig. 3). The tillage system did not significantly explain the ant compositional assemblage structure (Pillai Trace $=0.011 ; \mathrm{F}=$ $0.075 ; \mathrm{gl}=2$ and $13 ; \mathrm{p}=0.928)$, nor the seasons of the year $($ Pillai Trace $=0.144 ; \mathrm{F}=1.092 ; \mathrm{gl}=2$, and $13 ; \mathrm{p}=0.364)$, nor the interaction between system tillage and season (Pillai Trace $=0.002 ; \mathrm{F}$ $=0.013 ; \mathrm{gl}=2$, and 13; $\mathrm{p}=0.987)$.

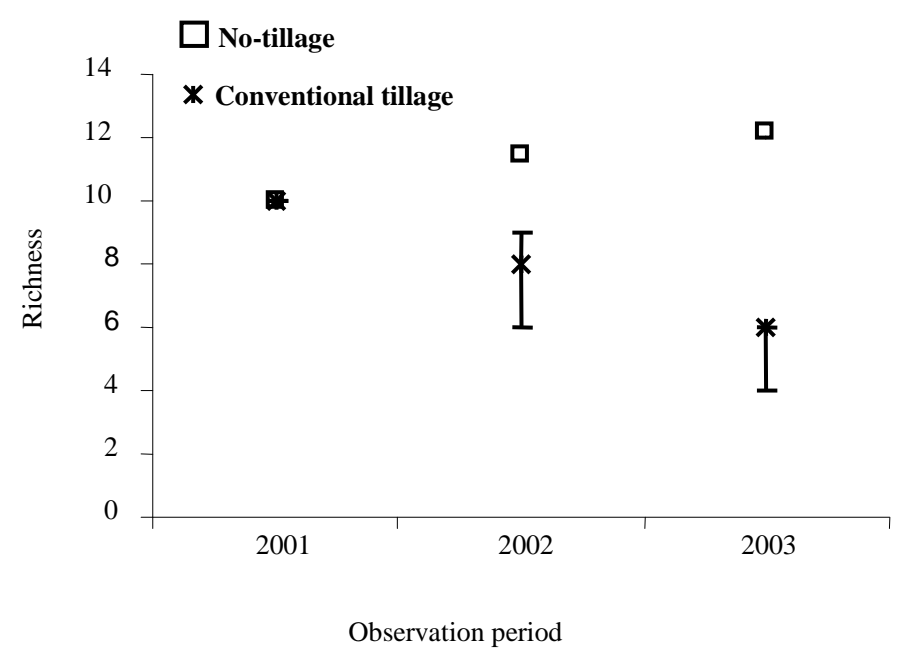

Figure 2 - Expected richness in 3-years observations in conventional tillage and no-tillage areas. Estimation and confidence interval were obtained by rarefaction of the number of baits kept by ants in both areas, in each observation year. The vertical bar shows the richness confidence interval (CI 95\%) for conventional tillage.

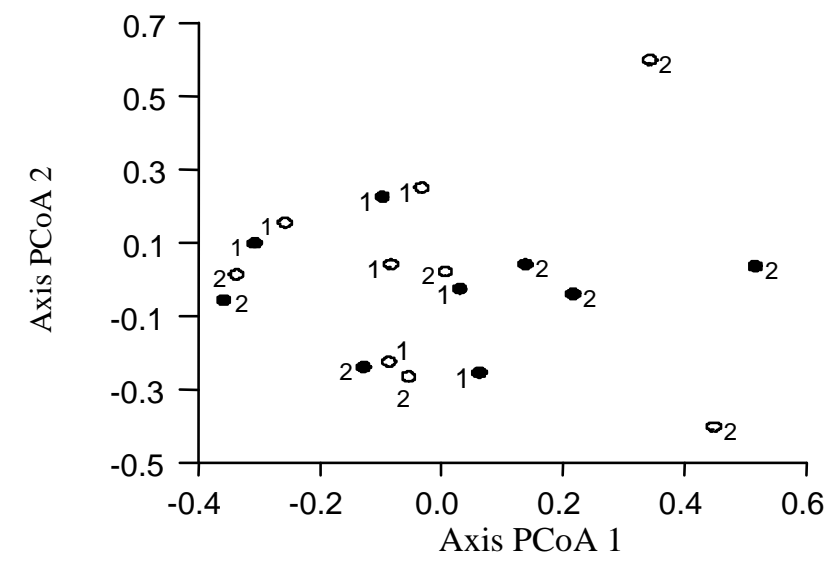

Figure 3 - Ordination by principal coordinates analysis (PCoA) of ant species samples in conventional (black circles) and no-till (open circles) systems, during rainy (1) and dry (2) season. Eigen value 1.102 from axis PCoA 1, and 0.923 from axis PCoA 2. 


\section{DISCUSSION}

The larger numbers of the ants of the subfamily Myrmicinae were mainly due to species of this group which is the most abundant in the subtropical areas, and has massive recruitment foraging habits. Thus concentrates large numbers of the individuals in the baits. Species of the genera Pheidole and Solenopsis were the most abundant, and quickly responded to the stimuli of baits in the soil.

Barbosa and Fernandes (2003) reported similar results in areas with Eucalyptus urophyla, with and without understory vegetation management; species of the genus Pheidole were the most frequent and most abundant in the baits offered in both the systems. Species belonging to these genera usually had aggressive behaviors and were the first to arrive to bait. These species, thus, inhibited the activity of others, with diversified foraging characteristics.

Ectatomma and Odontomachus are primarily predators that forage alone and without the recruitment, and therefore, attack the baits less frequently (Fowler et al., 1991). In Cruz das Almas municipality, Bahia state, Santos and Marques (1996) found that the main food source for E. quadridens Fabricius were the insects, particularly the termites and leaf-cutting ants, considered important pests in the agroecosystems. Ectatomma workers have a high diversity of the specialized foraging behaviors; they have been found in extra-floral nectaries, predating insect eggs and attacking smaller insects and dead insects (Franz and Wcislo, 2003). The ants of the genus Odontomachus are generalist predators of the small invertebrates and can be found foraging on the soil surface at day and night, as well as in low vegetation and tree trunks (Briese and Macauley, 1981).

In a study on the impact of the ant predation on Helicoverpa armigera Hübner (Lepidoptera: Noctuidae) eggs in the cotton monoculture in Australia, Mansfield et al. (2003) found that most eggs were attacked by the ants belonging to the genus Pheidole. Species of the genus Solenopsis are the most abundant group of the predators in the agroecosystems, therefore are important predators of a wide variety of the insects, including the pests of several crops (Eubanks, 2001). These species are among the most aggressive in using the resources available in the burlap and are frequently found in both the agroecosystems and native environments (Delabie and Fowler, 1995; Marinho et al., 2002).

The largest proportion of the baits removed in the no-till system was possibly due to a higher environmental complexity, with a larger quantity of vegetal litter in the soil and consequently, a richer variety of the species in the cropping system. According to Mussury et al. (2002), the mesofauna density was low at the conventional plantation series, especially collembolan families. The variations in the arthropod density could occur in the crops, particularly due to differences in the rainfall (Tonhasca Jr. and Stinner, 1991; Tonhasca Jr., 1993), temperature and humidity (Ruano et al., 2000; Hölldobler and Wilson, 1990), as well as by the nest proximity, time, temperature, humidity and food availability (Carroll and Janzen, 1973). Foraging has been observed in a variety of environments, increasing in the summer and decreasing in the winter (Lindsey and Skinner, 2001).

Although a larger number of the species was found in the no-till plots, no significant difference was observed in the assemblage structure between the two contiguous areas. Because both the areas were relatively small and contiguous, the exchange of the ant species might have occurred frequently and thus, the ant species composition was the same between the areas. When each year was analyzed separately, the expected number of the species for each area increased further apart after the first observation year. Probably, this situation was showing the importance of the environmental complexity. The no-till system led to the accumulation of the vegetal biomass in the soil, which increased the numbers of the niches, thus improving the possibility of the biodiversity increment. Higher richness of the preys in the notill environment may have contributed for an increase in the richness of the predacious ants. This result supported the natural enemies hypothesis (Root, 1973), which state that the more complex the environment, the higher would be the microhabitat and the prey diversity levels, following more stable populations of the generalist predators (see also Altieri et al., 2003 and Greenslade and Greenslade, 1977).

A lower plant biomass reduces the diversity of the microhabitats and resources, affecting the spatial distribution of the ant species and decreasing the local diversity. The maintenance of a complex litter structure allows the availability of nidification sites which are important in increasing 
the ant species diversity in the tropical regions (Benson and Harada, 1988). The no-till system drive to an increase in the ant richness, population density and foraging activities over time, which can guide to a more efficient biological control of the insects considered pests. Some authors found that the higher densities of these arthropods for controlling the crop pests reduced the number of the insecticide applications (Brust and House, 1990; Brust, 1991; Clark et al., 1994). Barbosa and Fernandes (2003) also observed greater richness, diversity, and equitability of the ant fauna in the understory areas with more complex E. urophylla. In an experiment with the baits, however, they found a higher proportion of the bait removal in the areas under the management and explained that the areas with the higher plant complexity made available larger quantities of the food resources, thus avoiding the competition for baits offered.

Many studies also have shown that not only the ant, but also the carabid (Coleoptera) and spider (Araneae) densities increased with the crop management techniques that reduced the soil tillage (Stinner and House, 1990; Clark et al., 1997). The tillage system also affects the physiochemical-biological soil complex, causing several kinds of the responses among the population and in the diversity levels of the organisms living in this environment (Kladivko, 2001).

Results suggested that the ant foraging activity responded to the soil tillage. The significant differences at the foraging activity and the ant richness between the areas showed that the notillage could improve the environmental quality of the cropping system and therefore, would be an important tool for integrated pest management programs. Nonetheless, further studies are needed to assess the effects of the no-tillage in the cropping systems in detail.

\section{ACKNOWLEDGMENT}

We thank professors John Latke, Donati Agosti, José Henrique Shoereder, Rogério Silvestre, Maria Eugênia Carvalho do Amaral and Manoel Araécio Uchôa-Fernandes, for revising this text; and the students, Odair Santo Gossler, Sabrina de Ávila Pereira, Michelle Viscardi Sant'Ana, Vitor Rafael Regiani, and Rui Alexandre Pereira Faria, for collaborating during the field work. We also thank the Conselho Nacional de Desenvolvimento
Científico e Tecnológico (CNPq), for awarding the scholarships to D. Lange (process 132219/2003-4) and J. Raizer (process 150596/03-3), and to the Fundação de Apoio ao Desenvolvimento do Ensino, Ciência e Tecnologia do Estado de Mato Grosso do Sul (FUNDECT-MS) for the financial support.

\section{RESUMO}

O objetivo do trabalho foi avaliar se a atividade de forrageamento de formigas predadoras em agroecossistemas varia entre duas áreas, uma com sistema de cultivo direto e outra com cultivo convencional. A pesquisa foi realizada em Dourados, MS, de fevereiro de 2001 a dezembro de 2003 em duas áreas contíguas de 1,5 ha cada. Como isca utilizou-se cupins do gênero Nasutitermes. Em cada área foram colocadas 750 iscas, sendo 425 durante o dia e 325 à noite. Cada cupim permanecia exposto sobre o solo por 15 minutos, ou até ser atacado. Foram encontradas 16 espécies de formigas no plantio direto e nove no convencional. A proporção de iscas retiradas por formigas no plantio direto $(167$ de 750$)$ e convencional (97 de 750) dependeu do turno de amostragem. Nos dois turnos a proporção de iscas removidas por formigas foi significativamente maior no plantio direto. As estações do ano não explicaram significativamente as variações na estrutura da comunidade de formigas nas áreas. As variações observadas em atividade de forageamento e em riqueza de espécies de formigas predadoras entre as duas áreas que diferiam em sistema de cultivo, indicam que o sistema de cultivo direto acrescentou uma melhora ambiental, tornando-se assim uma importante ferramenta para programas de manejo integrado de pragas.

\section{REFERENCES}

Alonso, L. E. and Agosti, D. (2000), Biodiversity studies, monitoring, and ants: An overview. In: Agosti, D.; Majer, J.D.; Alonso, L.E. and Schultz, T.R. (Eds.). Ants, standard methods for measuring and monitoring biodiversity, 4 ed. Smiths. Instit. Press. pp. 1-8.

Altieri, A. A.; Silva, E. N. and Nicholls, C. I. (2003), As bases ecológicas do manejo de pragas em agroecossistemas diversificados. In: Altieri, A.A., 
Silva, E.N. and Nicholls, C.I. (Eds.). O papel da biodiversidade no manejo de pragas. Editora Holos. $226 \mathrm{pp}$.

Barbosa, L. P. and Fernandes, W. D. (2003), Bait removal ants (Hymenoptera: Formicidae) in managed and unmanaged Eucalyptus urophylla S.T. BLAKE fields. Brazilian. Journal of Ecology, 5 e 6, 61-63.

Benson, W. W. and Harada, A. Y. (1988), Local diversity of tropical and temperate ant faunas (Hymenoptera, Formicidae). Acta Amazonica, 18, 275-289.

Bolton, B. (1994), Identification guide to the ant genera of the world. London, England: Harvard Univer. Press. 222 pp.

Bray, J. R. and Curtis, J. T. (1957), An ordination of the upland forest communities of southern Wisconsin. Ecological Monographs, 27, 325-349.

Briese, D. T. and Macauley, B. J. (1981), Food collection within an ant community in semi-arid Australia, with special reference to seed harvesters. Austral Ecology, 6, 1-19.

Brust, G. E. (1991), A method for observing belowground pest predator interactions in corn agroecosystems. Journal of Entomological Science, 26, 1-8.

Brust, G. E. and House, G. J. (1990), Effects of soil moisture, no tillage and predators on Southern corn rootworm (Diabrotica undecimpunctata Howardi) survival in corn agroecosystem. Agricultural. Ecosystem Environment, 31, 199-215.

Carroll, C. R. and Janzen, D. H. (1973), Ecology of foraging ants. Annual Review of Ecology and Systematics, 4, 231-257.

Clark, M. S.; Luna, J. M.; Stone, N. D. and Youngman, R. R. (1994), Generalist predator consumption of armyworm (Lepidoptera: Noctuidae) and effect of predator removal on damage in no-till corn. Environmental Entomology, 23, 617-622.

Clark, M. S.; Gage, S. H. and Spence, J. R. (1997), Habitats and management associated with common ground beetles (Coleoptera: Carabidae) in a Michigan agricultural landscape Environmental Entomology., 26, 519-527.

Delabie, J. H. C and Fowler, H. G. (1995), Soil and litter cryptic ant assemblages of Bahian cocoa plantations. Pedobiology, 39, 423-433.

Estrada, M. C. and Fernández, F. C. (1999), Diversidad de hormigas (Hymenoptera: Formicidae) en un gradiente sucesional del bosque nublado (Nariño, Colombia). Revista de Biologia Tropical, 47, 189-21.

Eubanks, M. D. (2001), Estimates of the direct and indirect effects of red imported fire ants on biological control in field crops. Biological Control, 21, 35-43.

Fernandes, W. D.; Reis, L. A. G. and Parré, J. C. (1999), Formigas como agentes de controle natural de pragas em plantações de milho com plantio direto e convencional. Naturalia, 24, 237-239.
Fernandes, W. D.; Cruz, M. C. A.; Faccenda, O., Gonzáles, M. S. and Valente, T. O. (2000), Impacto de herbicidas em uma guilda de formigas predadoras em Dourados, MS. Revista Brasileira de Herbicidas, 1, 225-231.

Fowler, H. G.; Forti, L. C.; Brandão, C. R. F.; Delabie, J. H. C. and Vasconcelos, H. L. (1991), Ecologia nutricional de formigas. In: Panizzi, A.R.; Parra, J.R.P. (Eds.), Ecologia nutricional de insetos e suas implicações no manejo de pragas. Ed. Manole e CNPq. p. 131-223.

Franz, N. M. and Wcislo, W. T. (2003), Foraging behavior in two species of Ectatomma (Formicidae: Ponerinae): individual learning of orientation and timing. Journal of Insect Behavior, 16, 382-410.

Garcia, M. A. and Altieri, M. A. (1992), Explaining differences in flea beetle Phyllotreta cruciferae Goeze densities in simple and mixed broccoli cropping systems as a function of individual behavior. Entomologia Experimentalis et Applicata, 62, 201-209.

Gassen, D. N. (1989), Insetos subterrâneos prejudiciais às culturas no sul do Brasil. Passo Fundo, Ed. EMBRAPA-CNPT, Documento 13, 49 pp.

Gotelli, N. J. and Entsminger, G. L. (2001), EcoSim: Null models software for ecology. Version 7.0. Acquired Intelligence Inc. and Kesey-Bear. http://homepages.together.net/ gentsmin/ecosim.htm

Greenslade, P. J. M. and Greenslade, P. (1977), Some affects of vegetation cover and abundance on a tropical ant fauna. Insectes Sociaux, 24, 163-182.

Hölldobler, B. and Wilson, E. O. (1990), The ants. Harvard University Press, Cambridge, MA. 732 p.

Kladivko, E. J. (2001), Tillage systems and soil ecology. Soil and Tillage Research, 61, 61-76.

Lindsey, P. A. and Skinner, J. D. (2001), Ant composition and activity patterns as determined by pitfall trapping and other methods in three habitats in the semi-arid Karoo. Journal of Arid Environments, 48, 551-568.

Mansfield, S.; Elias, N. V. and Lytton-Hitchins, J. A. (2003), Ants as egg predators of Helicoverpa armigera (Hübner) (Lepidoptera: Noctuidae) in Australian cotton crops. Australian Jounal of Entomology, 42, 349-351.

Marinho, C. G. S.; Zanetti, R.; Delabie, J. H. C.; Schlindwein, M. N. and Ramos, L. S. (2002), Diversidade de Formigas (Hymenoptera: Formicidae) da Serapilheira em Eucaliptais (Myrtaceae) e Área de Cerrado de Minas Gerais. Neotropical Entomology, 31, 187-195.

Mussury, R. M.; Scalon, S.P.Q.; Silva, S.V. and Soligo, V.R. (2002), Study of Acari and Collembola Populations in Four Cultivation Systems in Dourados - MS. Brazilian Archives of Biology and Technology, 45, 257-264. 
Risch, S. J. and Carroll, C. R. (1982), The ecological role of ants in two Mexican agroecosystems. Oecologia, 55, 114-119.

Root, E. P. (1973), Organization of a plant-arthropod association in simple and diverse habitats: the fauna of collards (Brassica oleracea). Ecological Monographs, 43, 95-124.

Rossi, M. N. and Fowler, H. G. (2004) Predaceous ant fauna in new sugarcane fields in the state of São Paulo, Brazil. Brazilian Archives of Biology and Technology, 47, 805-811.

Ruano, F.; Tinaut, A. and Soler, J. J. (2000). High surface temperatures select for individual foraging in ants. Behavioral Ecology, 11, 396-404.

Saks, M. E. and Carroll, R. (1980), Ant foraging activity in tropical agro-ecosystems. AgroEcosystems, 6, 177-188.

Samways, M. J. (1983), Community structure of ants (Hymenoptera: Formicidae) in a series of habitats associated with citrus. Journal of Applied Ecology, 20, 833-847.
Santos, G. M. M. and Marques, O. M. (1996), Análise faunística de comunidades de formigas epígeas (Hymenoptera: Formicidae) em dois agroecossistemas em Cruz das Almas-Bahia. Insecta, $5,1-17$.

Sterling, W. (1978), Fortuitous biological suppression of the boll weevil by the red imported fire ant. Environmental Entomolology, 7, 564-568.

Stinner, B. R. and House, G. J. (1990), Arthropods and other invertebrates in conservation-tillage agriculture. Annual Review of Entomology, 35, 299-318.

Tonhasca Jr., A. (1993), Effect of agroecosystem diversification on natural enemies of soybean herbivores. Entomologia Experimentalis et Applicata, 69, 83-90.

Tonhasca Jr., A. and Stinner, B. R. (1991), Effects of strip intercropping and no tillage on some pests and beneficial invertebrates of corn in Ohio. Environmental Entomolology, 20, 1251-1258. 


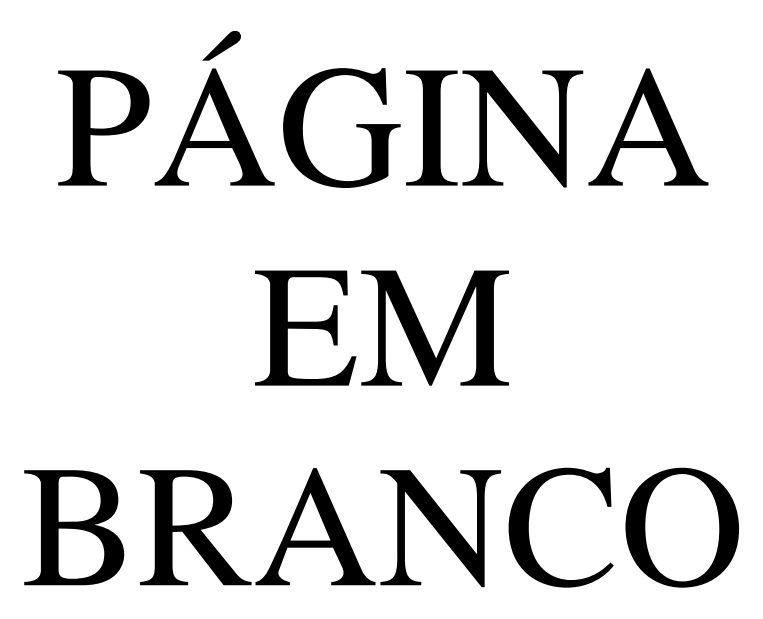

